\title{
Chemical contribution to future tropical ozone change in the lower stratosphere
}

\author{
S. Meul ${ }^{1}$, U. Langematz ${ }^{1}$, S. Oberländer ${ }^{1}$, H. Garny ${ }^{2}$, and P. Jöckel ${ }^{2}$ \\ ${ }^{1}$ Institut für Meteorologie, Freie Universität Berlin, Berlin, Germany \\ ${ }^{2}$ Deutsches Zentrum für Luft- und Raumfahrt, Institut für Physik der Atmosphäre, Oberpfaffenhofen, Germany
}

Correspondence to: S. Meul (stefanie.meul@met.fu-berlin.de)

Received: 4 September 2013 - Published in Atmos. Chem. Phys. Discuss.: 29 October 2013

Revised: 11 February 2014 - Accepted: 14 February 2014 - Published: 25 March 2014

\begin{abstract}
The future evolution of tropical ozone in a changing climate is investigated by analysing time slice simulations made with the chemistry-climate model EMAC. Between the present and the end of the 21st century a significant increase in ozone is found globally for the upper stratosphere and the extratropical lower stratosphere, while in the tropical lower stratosphere ozone decreases significantly by up to $30 \%$. Previous studies have shown that this decrease is connected to changes in tropical upwelling. Here the dominant role of transport for the future ozone decrease is confirmed, but it is found that in addition changes in chemical ozone production and destruction do contribute to the ozone changes in the tropical lower stratosphere. Between 50 and $30 \mathrm{hPa}$ the dynamically induced ozone decrease of up to $22 \%$ is amplified by $11-19 \%$ due to a reduced ozone production. This is counteracted by a decrease in the ozone loss causing an ozone increase by $15-28 \%$. At $70 \mathrm{hPa}$ the large ozone decrease due to transport $(-52 \%)$ is reduced by an enhanced photochemical ozone production $(+28 \%)$ but slightly increased $(-5 \%)$ due to an enhanced ozone loss. It is found that the increase in the ozone production in the lowermost stratosphere is mainly due to a transport induced decrease in the overlying ozone column while at higher altitudes the ozone production decreases as a consequence of a chemically induced increase in the overlying ozone column. The ozone increase that is attributed to changes in ozone loss between 50 and $30 \mathrm{hPa}$ is mainly caused by a slowing of the $\mathrm{ClO}_{\mathrm{x}}$ and $\mathrm{NO}_{\mathrm{x}}$ loss cycles. The enhanced ozone destruction below $70 \mathrm{hPa}$ can be attributed to an increased efficiency of the $\mathrm{HO}_{\mathrm{x}}$ loss cycle. The role of ozone transport in determining the ozone trend in this region is found to depend on the changes in the net production as a reduced net production also re-
\end{abstract}

duces the amount of ozone that can be transported within an air parcel.

\section{Introduction}

Studying the evolution of stratospheric ozone $\left(\mathrm{O}_{3}\right)$ in the 21st century is still of great interest not only to estimate the effect of the Montreal Protocol and its amendments but also to understand how increasing anthropogenic greenhouse gas (GHG) emissions will affect ozone. For the annual mean extratropical total ozone column a future increase is predicted by state-of-the-art chemistry-climate models (CCMs), which will result in a recovery to 1980 values by the end of the $21 \mathrm{st}$ century (e.g. Austin et al., 2010; SPARC CCMVal, 2010; Oman et al., 2010; WMO, 2011). In the tropics, however, the models show no return of the ozone column to levels before 1980. This different evolution is due to a significant decrease of the partial ozone column in the lower stratosphere (e.g. Austin et al., 2010), which is explained by an increase in tropical upwelling related to increasing concentrations of long-lived GHGs and a concomitant increase in the sea surface temperatures (SSTs; e.g. Garny et al., 2011a). Since in the tropical lower stratosphere isentropic horizontal mixing is weak because of the subtropical transport barriers (e.g. McIntyre and Palmer, 1984), this region is quasi-isolated from midlatitudes and the budgets of chemical compounds are determined by a balance of mean upwelling and chemical production and loss (Plumb, 1996). Avallone and Prather (1996) confirmed this connection between the velocity of rising air parcels in the tropics and the mixing ratios of ozone in the lower tropical stratosphere. Hence, the abundance of 
ozone in this region is primarily determined by the balance of net ozone production and the rate of ascent. The faster the air rises the less ozone is produced in the air parcel and the less ozone is present in this region. Accordingly, Waugh et al. (2009) and Oman et al. (2010) explained the negative ozone trend with a reduced transit time of air parcels through the tropical lower stratosphere and therefore a reduced accumulation of ozone in this region.

The net ozone production in a pure oxygen atmosphere is determined by the Chapman cycle (Chapman, 1930). In this cycle ozone is produced by the photolysis of molecular oxygen $\left(\mathrm{O}_{2}\right)$, while the reaction between ozone and atomic oxygen $(\mathrm{O})$ leads to the destruction of ozone. The photolysis of ozone and the reaction between molecular and atomic oxygen, which are also part of the Chapman cycle, do not contribute to the production or loss of ozone, but cause a fast inter-conversion between ozone and atomic oxygen. Because of this fast interaction, $\mathrm{O}_{3}$ and $\mathrm{O}$ can be combined in the odd oxygen family $\mathrm{O}_{\mathrm{x}}$ (Seinfeld and Pandis, 2006). The atmosphere, however, consists not only of oxygen compounds. In addition to the Chapman loss reaction, catalytic loss cycles, which involve hydrogen, nitrogen, chlorine or bromine radicals, contribute substantially to the ozone destruction (e.g. Bates and Nicolet, 1950; Crutzen, 1970; Molina and Rowland, 1974).

The abundance of tropical ozone is also influenced by the phase of the quasi-biennial oscillation (QBO) in the equatorial zonal winds and the temperature (e.g. Randel and $\mathrm{Wu}$, 1996). However, in the long-term mean this approximate two-year cycle in ozone is nearly canceled and therefore unimportant for the analysis of long-term changes.

In a future climate it is not only the tropical upwelling and the accumulation of ozone that will change due to increased GHG concentrations. The atmospheric concentrations of substances acting as catalysts for ozone destruction as well as the stratospheric temperature will change and will thus modify the chemical loss rates. The stratospheric loading of halogens will decline due to the successful regulation of ozone depleting substances (ODSs) and is predicted to reach pre-1980 values in the second half of the 21 st century (e.g. Newman et al., 2007). Throughout the stratosphere this will result in a significantly reduced chemical ozone loss due to the reduced abundance of chlorine and bromine radicals. At the same time, the increase in the concentrations of the GHGs, primarily carbon dioxide $\left(\mathrm{CO}_{2}\right)$, will cause a significant cooling of the stratosphere (e.g. IPCC, 1996, 2001). This has a direct effect on ozone chemistry as the rate of most chemical reactions is temperature dependent. The impact of a temperature decrease on ozone is found to result primarily from the increased rate of the three-body reaction $\mathrm{O}+\mathrm{O}_{2}+$ $M \rightarrow \mathrm{O}_{3}+M$ which leads to a changed partitioning of odd oxygen in favour of ozone instead of atomic oxygen (Rosenfield et al., 2002; Jonsson et al., 2004). In the upper stratosphere the reactions with atomic oxygen are the rate limiting steps in the catalytic ozone loss cycles. Therefore, a decrease in atomic oxygen causes a reduction in the efficiency of the loss cycles without changing the concentrations of the radicals. Another contribution to the ozone increase in a cooler stratosphere is the temperature induced decrease in the rate coefficient of the $\mathrm{O}_{3}+\mathrm{O}^{3} \mathrm{P} \rightarrow 2 \mathrm{O}_{2}$ reaction that describes the net loss pathway of the Chapman cycle (e.g. Jonsson et al., 2004). Besides the impact of GHG induced temperature changes on the chemistry, also the increasing abundances of methane $\left(\mathrm{CH}_{4}\right)$ and nitrous oxide $\left(\mathrm{N}_{2} \mathrm{O}\right)$ will affect stratospheric ozone chemistry. $\mathrm{N}_{2} \mathrm{O}$ is an important source of nitrogen oxides in the stratosphere (e.g. Bates and Hays, 1967), while the oxidation of $\mathrm{CH}_{4}$ is relevant for the production of stratospheric water vapour $\left(\mathrm{H}_{2} \mathrm{O}\right)$ and hence for the production of the hydroxyl radical OH (e.g. Seinfeld and Pandis, 2006). Thus, the efficiency of the catalytic ozone loss cycles involving nitrogen and hydrogen radicals can be modified. Revell et al. (2012) show that the increase in $\mathrm{N}_{2} \mathrm{O}$ surface concentrations between the 1960s and the 2090s will lead to a slightly enhanced ozone loss rate in the tropical upper stratosphere, but to a slowing of the rate elsewhere. The ozone loss rate due to an increase in $\mathrm{CH}_{4}$ and hence in hydrogen radicals is predicted to increase in the upper stratosphere during the 21st century (e.g. Portmann and Solomon, 2007; Revell et al., 2012). Additionally, a change in the ozone column above a certain layer will modify locally the downward flux of shortwave (SW) solar radiation and will therefore affect the ozone production via photolysis in the underlying layers (e.g. Haigh and Pyle, 1982).

In this study we analyse in detail to which extent the projected changes in stratospheric composition and temperature will affect the ozone chemistry in the tropical lower stratosphere. The ultimate goal is to quantify if and how these chemically induced ozone changes contribute to the total negative ozone change in this region which is generally attributed to dynamical changes. Moreover, it is examined which processes are relevant for the detected chemical ozone changes. For this purpose simulations with a state-of-the-art CCM have been carried out in which the simulated ozone changes have been split into the contributions from transport and chemistry. The causes for the changes in the chemical ozone production and loss are studied by separating the different production and loss pathways with the help of the tool StratO3Bud which is described here for the first time.

The study is composed as followed: first we describe the model and the experimental set-up used for the analysis (Sect. 2). Then the different methods of analysis and the postprocessing tool StratO3Bud are explained (Sect. 3). In Sect. 4 the results are presented and discussed. Finally, the conclusions are drawn (Sect. 5).

\section{Model and experimental set-up}

For this study three simulations have been performed at the Freie Universität Berlin with the ECHAM/MESSy 
Table 1. Boundary conditions for the three time slice simulations. Obs stands for observations.

\begin{tabular}{cccc}
\hline & R2000 & R2095 & GHG2095 \\
\hline GHGs & Obs for 2000 & IPCC A1b for 2095 & IPCC A1b for 2095 \\
ODSs & Obs for 2000 & WMO adjusted A1 for 2095 & Obs for 2000 \\
modelled & modelled & modelled \\
& $(1995-2004$ mean $)$ & $(2090-2099$ mean $)$ & $(2090-2099$ mean $)$ \\
\hline
\end{tabular}

Atmospheric Chemistry (EMAC) CCM in the version 1.7 (Jöckel et al., 2006). The core atmospheric model is the European Centre Hamburg general circulation model (GCM) in the 5th generation (ECHAM5, Roeckner et al., 2006). This GCM is coupled to the atmospheric chemistry module MECCA (Module Efficiently Calculating the Chemistry of the Atmosphere, Sander et al., 2005) via the Modular Earth Submodel System (MESSy1). The model is used with the standard set of submodels which ensures that the most important physical processes (e.g. convection, radiation) are included. Additionally, the FUBRad parameterisation (Nissen et al., 2007) is applied as the SW radiation scheme. The model is used in the horizontal resolution $\mathrm{T} 42\left(2.8^{\circ} \times 2.8^{\circ}\right)$ and with 39 hybrid model layers between the surface and $0.01 \mathrm{hPa}(\sim 80 \mathrm{~km})$. The sea surface temperatures (SSTs) and sea ice concentrations (SICs) are prescribed.

Three multi-year equilibrium simulations (i.e. in timeslice mode with fixed boundary conditions but including an annual cycle) have been performed. The model has been integrated at least over 20 years after a spin-up time of two years. The first simulation represents the reference state of the atmosphere for present day conditions (R2000) with observed mixing ratios of the well-mixed GHGs $\left(\mathrm{CO}_{2}, \mathrm{CH}_{4}\right.$, $\mathrm{N}_{2} \mathrm{O}$ ) from IPCC (2001) and the ODSs from WMO (2007). The second simulation represents the future atmosphere at the end of the 21st century (R2095), as it is predicted based on the moderate GHG scenario A1B (IPCC, 2000) and the adjusted A1 scenario for ODSs (WMO, 2007). This means an increase of the boundary mixing ratios by $87 \%$ for $\mathrm{CO}_{2}, 15 \%$ for $\mathrm{CH}_{4}$ and $17 \%$ for $\mathrm{N}_{2} \mathrm{O}$. The mixing ratio of organic chlorine in the troposphere is reduced by $63 \%$ between 2000 and 2095. The prescribed SSTs and SICs are 10-year averages for the particular periods using the model output from a transient simulation with the coupled atmosphere ocean model ECHAM5/MPIOM (Max-PlanckInstitute Ocean Model, Jungclaus et al., 2006) for the equivalent scenario. Averaging is necessary to ensure neutral conditions of the El Niño-Southern Oscillation (ENSO), but it must be noted that it also reduces the inter-annual variability of the SSTs. Further information on the simulations and a detailed analysis of dynamical changes in the future is found in Oberländer et al. (2013).

To study the impact of increasing GHGs on the evolution of ozone, a sensitivity study with the GHGs and SSTs/SICs changed to future conditions (GHG2095), but fixed ODSs has been performed. The boundary conditions used for the simulations are shown in Table 1. Natural forcings such as solar variability (e.g. the 11-year solar cycle), the QBO, ENSO or volcanic eruptions are not included in the simulations. Since the vertical velocity and the ozone abundance in the tropics are modulated by the phase of the QBO (e.g. Randel and Wu, 1996; Baldwin et al., 2001), in the time slice simulations the inter-annual variability of these quantities is considerably reduced in the tropics compared to transient simulations (not used in this study) including this equatorial oscillation. The mean state, however, is found to be comparable between the simulations with and without QBO. As the focus of this study is on long-term changes, the set-up of the simulations is appropriate.

\section{Methods}

\subsection{Ozone budgets}

The production and loss rates of ozone in the model simulations are calculated in two different ways: the total production and loss terms are obtained with the help of the MESSy tool ProdLoss, while the contributions from the single production processes and loss cycles are calculated with the tool StratO3Bud.

\subsubsection{Total production and loss}

The ozone tendencies due to chemical reactions are calculated in the chemistry module MECCA. However, no output of the production or loss terms integrated over all involved reactions (i.e. the total production and total loss) is given. With the help of the MESSy tool ProdLoss (http: //www.messy-interface.org), the calculation of the total production and the total loss is included in the online integration of the model. Based on the concept of Crutzen and Schmailzl (1983) only those reactions are chosen in ProdLoss and taken into account for the total production and loss, which represent effective loss and production terms, while rapid nullcycles are not considered.

As ozone and atomic oxygen are in rapid photochemical equilibrium in the stratosphere, the chemical budgets are calculated for the odd oxygen family $\mathrm{O}_{x}$ (i.e. $\mathrm{O}_{3}+\mathrm{O}^{3} \mathrm{P}+\mathrm{O}^{1} \mathrm{D}$ ). With ozone being the main constituent of $\mathrm{O}_{\mathrm{x}}$ in the stratosphere (e.g. Johnston and Podolske, 1978), the production 
and loss of ozone are approximated by the production and loss of odd oxygen. These terms are implemented in EMAC as diagnostic variables and are calculated every time step using the instantaneous temperature and trace gas concentrations as input.

\subsubsection{Production pathways and loss cycles}

As the atmospheric composition will change in the future due to modified anthropogenic and natural emissions, the relative importance of single ozone loss cycles is also expected to change. Therefore it is essential to separate the ozone loss into the loss due to the Chapman cycle $\left(\mathrm{O}_{\mathrm{x}}\right)$ and the catalytic cycles involving the hydrogen, nitrogen and halogen radicals. Equivalent to the calculation of the total loss and production rates, this separation could also be obtained during the model integration. However, this feature has not been used in our simulations. Therefore the separation of the chemical cycles is carried out by using the MESSy tool StratO3Bud (see the Supplement), which allows the approximate calculation offline (i.e. as a post-processing step) based on standard model output. In our study we applied StratO3Bud on the 6-hourly model output.

StratO3Bud allows us to calculate the stratospheric ozone budgets using the model output for the temperature and a set of chemical tracers (see the Supplement). The tool is based on the concept of chemical families (i.e. related chemical species with short lifetimes are combined). This allows a reduction of the full chemical loss cycles to the rate limiting steps. Here, the families of odd oxygen $\left(\mathrm{O}_{\mathrm{x}}\right)$, odd nitrogen $\left(\mathrm{NO}_{\mathrm{x}}=\mathrm{NO}+\mathrm{NO}_{2}\right)$, odd hydrogen $\left(\mathrm{HO}_{\mathrm{x}}=\mathrm{H}+\mathrm{OH}+\mathrm{HO}_{2}\right)$, odd chlorine $\left(\mathrm{ClO}_{\mathrm{x}}=\mathrm{Cl}+\mathrm{ClO}\right)$ and odd bromine $\left(\mathrm{BrO}_{\mathrm{x}}=\mathrm{Br}+\mathrm{BrO}\right)$ are used. The reaction pathways that are considered for the different loss cycles due to $\mathrm{O}_{\mathrm{x}}, \mathrm{NO}_{\mathrm{x}}, \mathrm{HO}_{\mathrm{x}}, \mathrm{ClO}_{\mathrm{x}}$ and $\mathrm{BrO}_{\mathrm{x}}$ are listed in Table 2. The ozone change over time due to a specific loss cycle is given by:

$$
\begin{aligned}
-\left.\frac{d}{d t}\left[\mathrm{O}_{3}\right]\right|_{i} & =k_{1 \_2}[\operatorname{species} 1][\text { species } 2]+ \\
& +k_{3 \_4}[\text { species } 3][\text { species } 4]+\ldots
\end{aligned}
$$

Here, the subscript $i$ denotes the ozone loss due to the $\mathrm{O}_{\mathrm{x}}$, $\mathrm{NO}_{\mathrm{x}}, \mathrm{HO}_{\mathrm{x}}, \mathrm{ClO}_{\mathrm{x}}$ or $\mathrm{BrO}_{\mathrm{x}}$ cycles. $\mathrm{k}_{1 \_2}$ is the (temperature dependent) reaction rate coefficient for the reaction between species1 (e.g. $\mathrm{NO}_{2}$ ) and species2 (e.g. $\mathrm{O}^{3} \mathrm{P}$ ) as it is used in the chemistry module MECCA. [species1] stands for the number density of species1. This study uses the rate coefficients according to the JPL 2006 recommendations (Sander et al., 2006), consistent with the EMAC simulations. The loss terms are obtained by integrating the corresponding differential equations at each grid point over time using the 6-hourly model data for the particular species and the temperature.

After the integration, the terms are converted back to volume mixing ratios for comparison with the online calculated fields of the total production and loss of ozone (ProdLoss).
Table 2. List of reactions that are rate determining for the different ozone production pathways and ozone loss cycles.

\begin{tabular}{cl}
\hline Production & Reactions \\
\hline $\begin{array}{c}\text { Photolysis } \\
\mathrm{HO}_{2}\end{array}$ & $\mathrm{O}_{2}+\mathrm{h} \nu \rightarrow \mathrm{O}^{3} \mathrm{P}+\mathrm{O}^{3} \mathrm{P}$ \\
$\mathrm{CH}_{3} \mathrm{O}_{2}$ & $\mathrm{CH}_{3} \mathrm{O}_{2}+\mathrm{NO} \rightarrow \mathrm{CH}_{3} \mathrm{O}+\mathrm{NO}_{2}$ \\
\hline Loss cycle & Reactions \\
\hline $\mathrm{O}_{\mathrm{x}}$ & $\mathrm{O}_{3}+\mathrm{O}^{3} \mathrm{P} \rightarrow 2 \mathrm{O}_{2}$ \\
\hline & $\mathrm{O}^{1} \mathrm{D}+\mathrm{H}_{2} \mathrm{O} \rightarrow 2 \mathrm{OH}$ \\
$\mathrm{NO}_{\mathrm{x}}$ & $\mathrm{NO} \mathrm{O}_{2} \mathrm{P} \rightarrow \mathrm{NO}+\mathrm{O}_{2}$ \\
$\mathrm{HO}_{\mathrm{x}}$ & $\mathrm{HO}+\mathrm{O}_{3} \rightarrow \mathrm{OH}+2 \mathrm{O}_{2}$ \\
& $\mathrm{OH}+\mathrm{O}_{3} \rightarrow \mathrm{HO}+\mathrm{O}_{2}$ \\
& $\mathrm{HO}+\mathrm{O}^{3} \mathrm{P} \rightarrow \mathrm{OH}+\mathrm{O}_{2}$ \\
& $\mathrm{OH}+\mathrm{O}^{3} \mathrm{P} \rightarrow \mathrm{H}+\mathrm{O}_{2}$ \\
\hline & $\mathrm{H}+\mathrm{O}_{3} \rightarrow \mathrm{OH}+\mathrm{O}_{2}$ \\
$\mathrm{ClO}_{\mathrm{x}}$ & $\mathrm{ClO}+\mathrm{O}^{3} \mathrm{P} \rightarrow \mathrm{Cl}+\mathrm{O}_{2}$ \\
& $\mathrm{ClO}+\mathrm{HO} \rightarrow \mathrm{HOCl}+\mathrm{O}_{2}$ \\
\hline & $\mathrm{ClO}+\mathrm{ClO}+\mathrm{M} \rightarrow \mathrm{Cl}_{2} \mathrm{O}_{2}+\mathrm{M}$ \\
$\mathrm{BrO}_{\mathrm{x}}$ & $\mathrm{BrO}+\mathrm{ClO} \rightarrow \mathrm{Br}+\mathrm{Cl}_{2}+\mathrm{O}_{2}$ \\
& $\mathrm{BrO}+\mathrm{ClO} \rightarrow \mathrm{BrCl}+\mathrm{O}_{2}$ \\
& $\mathrm{BrO}+\mathrm{O}^{3} \mathrm{P} \rightarrow \mathrm{Br}+\mathrm{O}_{2}$ \\
\hline & \\
& \\
&
\end{tabular}

The offline calculated total loss of ozone is defined as the sum of the losses from the five single loss cycles.

Figure 1a illustrates the contribution of the different loss cycles to the total ozone loss in the tropical stratosphere for the $R 2000$ reference simulation. It shows the dominant role of the nitrogen loss cycle in the middle stratosphere, while in the lower and upper stratosphere the hydrogen cycle determines the ozone loss. The ozone loss through chlorine and oxygen radicals peaks in the upper stratosphere between 3 and $2 \mathrm{hPa}$. The loss via the catalytic cycle involving bromine is constrained to the lower stratosphere. In the tropics, the inter- and intra-annual variability of the chemical production and loss rates is very small and therefore not shown. The variation of the relative importance of ozone loss cycles with height shown in Fig. 1a is consistent with other studies (e.g. IPCC/TEAP, 2005).

The ozone production is separated into the contributions from photolysis of oxygen and from methane photooxidation. During the oxidation of methane the hydroperoxyl radicals $\mathrm{HO}_{2}$ and $\mathrm{CH}_{3} \mathrm{O}_{2}$ are produced (e.g. Johnston and Kinnison, 1998). The reaction of these radicals with NO leads to the production of ozone. Therefore, the reactions of $\mathrm{NO}+\mathrm{HO}_{2}$ and $\mathrm{NO}+\mathrm{CH}_{3} \mathrm{O}_{2}$ are considered for ozone production in StratO3Bud.

The contribution from the different production pathways to the total ozone production is shown in Fig. 1b. In the lower stratosphere both the production due to $\mathrm{NO}+\mathrm{HO}_{2}$ and due to photolysis are important, but with increasing altitude the 

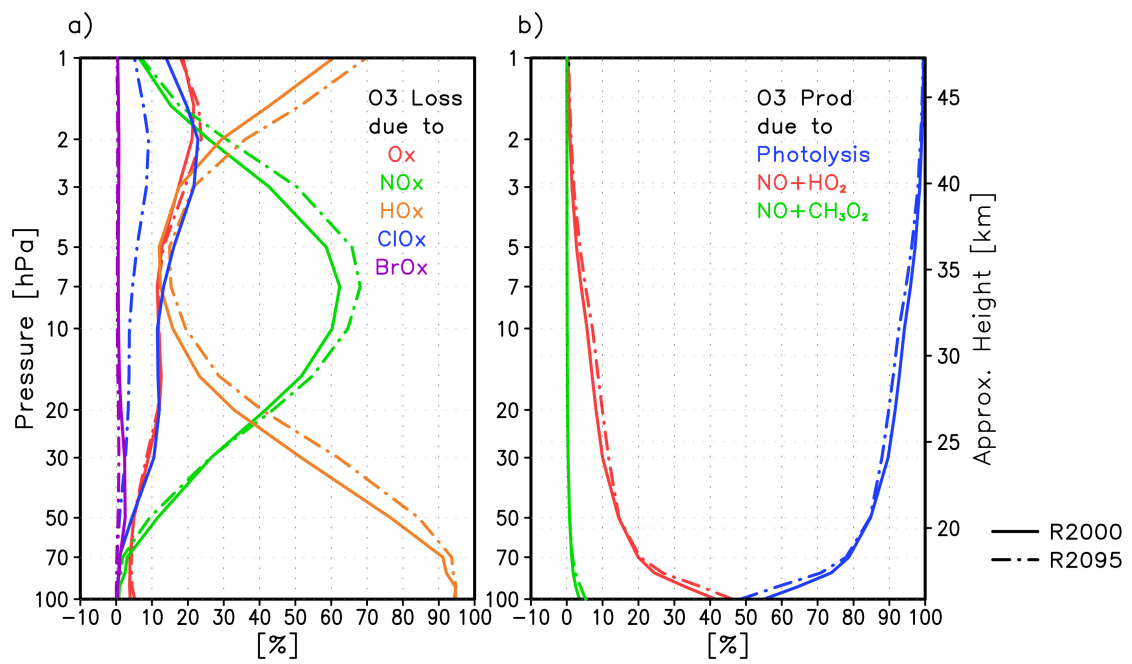

Fig. 1. Vertical profile of the annual mean relative contribution of (a) the different ozone loss cycles, that is, the $\mathrm{O}_{\mathrm{x}}(\mathrm{red}), \mathrm{NO}_{\mathrm{x}}(\mathrm{green})$, $\mathrm{HO}_{\mathrm{x}}$ (orange), $\mathrm{ClO}_{\mathrm{x}}$ (blue), and $\mathrm{BrO}_{\mathrm{x}}$ (magenta) loss cycles, and (b) the ozone production pathways, that is, via photolysis of oxygen (blue) and the reactions $\mathrm{NO}+\mathrm{HO}_{2}$ (red) and $\mathrm{NO}+\mathrm{CH}_{3} \mathrm{O}_{2}$ (green), to the sum in the tropics $\left(25^{\circ} \mathrm{S}-25^{\circ} \mathrm{N}\right)$ in $\%$ for the reference simulation $R 2000$ (solid) and the future simulation $R 2095$ (dash-dotted). The standard deviation of the multi-annual average is very small and therefore not shown.

contribution of the photolysis increases. Above $30 \mathrm{hPa}$, more than $90 \%$ of the ozone production is attributed to the photolysis of $\mathrm{O}_{2}$. The reaction $\mathrm{NO}+\mathrm{CH}_{3} \mathrm{O}_{2}$ represents an important production pathway in the troposphere (not shown) and lowermost stratosphere. In the middle and upper stratosphere, however, the contribution to the ozone production is irrelevant.

The separation of the production and loss cycles through post-processing the model data shows reasonable results, but it has to be noted that the total production and loss terms differ between the online and the offline calculations due to the reduced sampling rate and the reduced set of reactions taken into account in StratO3Bud. For the offline calculation only 6-hourly data have been available with the consequence that the minimum and maximum values of substances with large diurnal cycles cannot be captured well. This leads to differences mainly in the wintertime polar lower stratosphere. At all latitudes and in all seasons, a difference arises from the smaller set of chemical reactions that is used in StratO3Bud compared to the MESSy tool ProdLoss (see Sect.2), with largest discrepancies in the lower stratosphere. However, in the tropical stratosphere the disagreement is relatively small (maximum differences in the lower stratosphere: $1 \%$ in the production, $5-8 \%$ in the loss) and changes in these variables are qualitatively consistent (see Sect. 4).

\subsection{Long-term changes}

The causes of long-term ozone changes are analysed by applying the method described in Garny et al. (2011b). The relative ozone changes $\left(\mathrm{RO}_{3}\right)$ between two atmospheric equilibrium states 1 and 2 are separated into the relative ozone changes due to transport (R_T), production (R_P) and destruction (R_D). For this calculation it is required that the mean annual tendency of ozone is zero or small compared to the other terms, which is fulfilled in the case of time slice simulations. Furthermore, the ozone loss rate $(\mathrm{L}$ in $\mathrm{mol} / \mathrm{mol} / \mathrm{s}$ ) is expressed as the fraction of ozone that has been destroyed ( $\mathrm{D}$ in $1 / \mathrm{s})$ times the ozone volume mixing ratio $\left(\mathrm{O}_{3}\right.$ in $\mathrm{mol} / \mathrm{mol}$ ) at each grid point and each time step: $\mathrm{L}=\mathrm{D} \cdot \mathrm{O}_{3}$. It is assumed that the time integration of the ozone loss rate is approximated by the integration of $\mathrm{D}$ times the integration of $\mathrm{O}_{3}$.

Garny et al. (2011b) showed that the relative ozone changes between the atmospheric state 1 and 2 can then be approximated by the sum of the single contributions plus a non-linear term:

$$
\begin{aligned}
\mathrm{RO}_{3}=\frac{\mathrm{O}_{3}{ }^{2}-\mathrm{O}_{3}{ }^{1}}{\mathrm{O}_{3}{ }^{1}} & \approx \mathrm{R} \_\mathrm{T}+\mathrm{R} \_\mathrm{P}+\mathrm{R} \_\mathrm{D}+ \\
& +\mathrm{R} \_\mathrm{D} \cdot\left(\mathrm{R} \_\mathrm{T}+\mathrm{R} \_\mathrm{P}\right) .
\end{aligned}
$$

Here, the relative ozone change due to transport is defined as $\mathrm{R} \_\mathrm{T}=\left(\mathrm{T}_{2}-\mathrm{T}_{1}\right) /\left(\mathrm{P}_{1}+\mathrm{T}_{1}\right)$ with $\mathrm{T}_{i}$ and $\mathrm{P}_{i}$ (in mol mol ${ }^{-1}$ month $\left.^{-1}\right)$ denoting the transport and the production during the atmospheric state $i$. Analogously, the relative ozone change due to production is defined: $\mathrm{R} \_\mathrm{P}=\left(\mathrm{P}_{2}-\right.$ $\left.\mathrm{P}_{1}\right) /\left(\mathrm{P}_{1}+\mathrm{T}_{1}\right)$. The sum of production and transport is a quantity describing the source of ozone. The relative ozone change due to changes in the destruction is defined as $\mathrm{R} \_\mathrm{D}=\left(\mathrm{D}_{1}-\mathrm{D}_{2}\right) / \mathrm{D}_{2}$. In the following the sum of R_T, R_P, $\mathrm{R} \_\mathrm{D}$ and the non-linear term is denoted as $\mathrm{RO}_{3}^{*}$, that is, $\mathrm{RO}_{3}$ $\approx \mathrm{RO}_{3}^{*}$. 


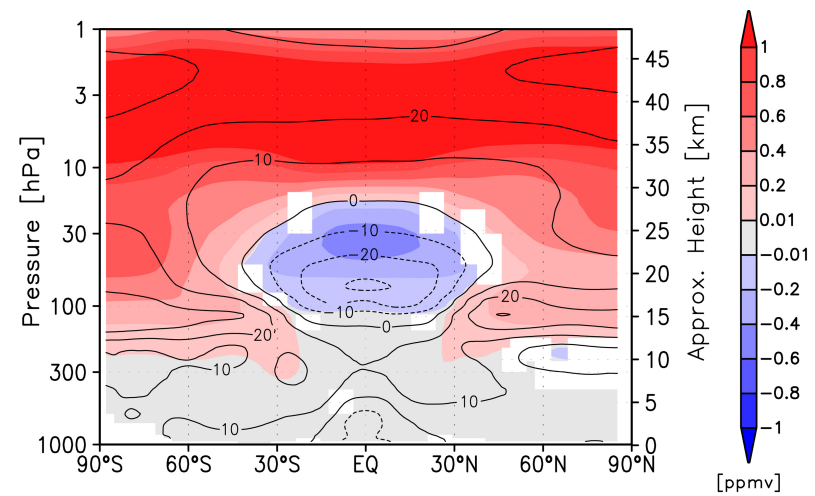

Fig. 2. Latitude-height section of the change in the annual mean zonal mean ozone mixing ratio between $R 2000$ and $R 2095$ in ppmv (red/blue shading indicates positive/negative changes). Statistically significant changes on the $99 \%$ confidence level are coloured. Black contours indicate the relative ozone change in $\%$, the contour interval is $10 \%$.

The non-linear term in Eq. (2) represents the contribution from interactions between changes in the destruction (R_D) and changes in ozone that is available for destruction ( $R_{-} T$ + R_P). It can be considered as a correction of the ozone change attributed to destruction changes because the amount of actual ozone loss does also depend on the available ozone. The non-linear term is small if the relative changes are small but can also have an important contribution to the relative ozone change.

The transport of ozone in the different simulations is derived from the assumption that the tendency of ozone over one month is determined by the sum of the monthly integrated ozone transport, production, and loss. Since the tendency, the production, and the loss terms (from ProdLoss) are known, the transport can be calculated as the residual for each month and grid point. For more details see Garny et al. (2011b). It has to be noted that with this method no information is given about the characteristics of the ozone transport, for example, if ozone is transported vertically or horizontally. Furthermore, changes in the transport cannot be clearly attributed to a change in the import or export of ozone. This gap can be filled by applying a diagnostic tool, which allows the identification of the region of chemical production for each ozone molecule in the model domain. This ozone origin diagnostic is explained in detail in Grewe (2006) and Garny et al. (2011b) and has been implemented in the EMAC version used here. With the help of this tool the region in the tropical lower stratosphere (tropopause $-30 \mathrm{hPa}$ ) can be characterized as a region with a net ozone export in all seasons (i.e. more ozone molecules are transported out of than into this region).

\section{Results}

\subsection{Contribution to long-term ozone changes}

The annual mean ozone change between the present $(R 2000)$ and the future $(R 2095)$ reference simulations is shown in Fig. 2. In the middle and upper stratosphere a significant global increase in ozone by $10-30 \%$ is found. In the lower stratosphere, however, the increase is confined to the extratropical regions with the largest relative changes in the southern polar lowermost stratosphere. In the tropical lower stratosphere the expected negative ozone trend is prominent in the simulations with a decrease by up to $30 \%$ in the annual mean. The maximum absolute changes in the tropical lower stratosphere of $-0.41 \mathrm{ppmv}$ at $30 \mathrm{hPa}$ are slightly larger than in other CCMs, while the ozone increase above $10 \mathrm{hPa}$ lies in the range of the models included in the study of Oman et al. (2010).

In order to isolate the causes of the tropical ozone decrease in detail, the ozone change at different lower stratospheric levels averaged over $25^{\circ} \mathrm{S}-25^{\circ} \mathrm{N}$ is split into the contributions from transport, production and destruction after Garny et al. (2011b) (Fig. 3, left column). The lowest level that is considered is $70 \mathrm{hPa}$. Here, the largest relative ozone changes occur and the air parcels are definitely located in the stratosphere, both, for the present and future conditions, whereas the region below is influenced by a future elevation of the tropical tropopause layer (not shown).

In the tropical lower stratosphere (70 and $50 \mathrm{hPa})$, the large relative ozone decrease between the years 2000 and 2095 is mainly attributed to transport processes. This result is consistent with the relation between the tropical lower stratospheric ozone abundance and tropical upwelling discussed in the literature (e.g. Austin et al., 2010; Oman et al., 2010; SPARC CCMVal, 2010; WMO, 2011). A significant enhancement of the tropical upwelling in the lower stratosphere between 2000 and 2095 can also be identified in the time slice simulations with EMAC used in this study (not shown). This leads to a stronger net export of ozone in the tropical lower stratosphere. With the help of the ozone origin diagnostic it is verified that the larger net export is driven by an increased export of locally produced ozone molecules and not by a reduction of the ozone import (not shown). As the main topic of this study is to analyse the role of ozone chemistry and not to detect the causes for changes in ozone transport, we will not go into further details here.

With increasing height the ozone change attributed to changes in transport becomes smaller and at $30 \mathrm{hPa}$ the relative changes due to production and destruction changes are dominant. While in the 50 and $30 \mathrm{hPa}$ layers the tropical ozone decrease due to transport is amplified by a reduced production, at $70 \mathrm{hPa}$ a positive contribution to the ozone changes is found from an increased production. Furthermore, a small future ozone decrease due to modified destruction rates is found at $70 \mathrm{hPa}$. However, the more ozone 

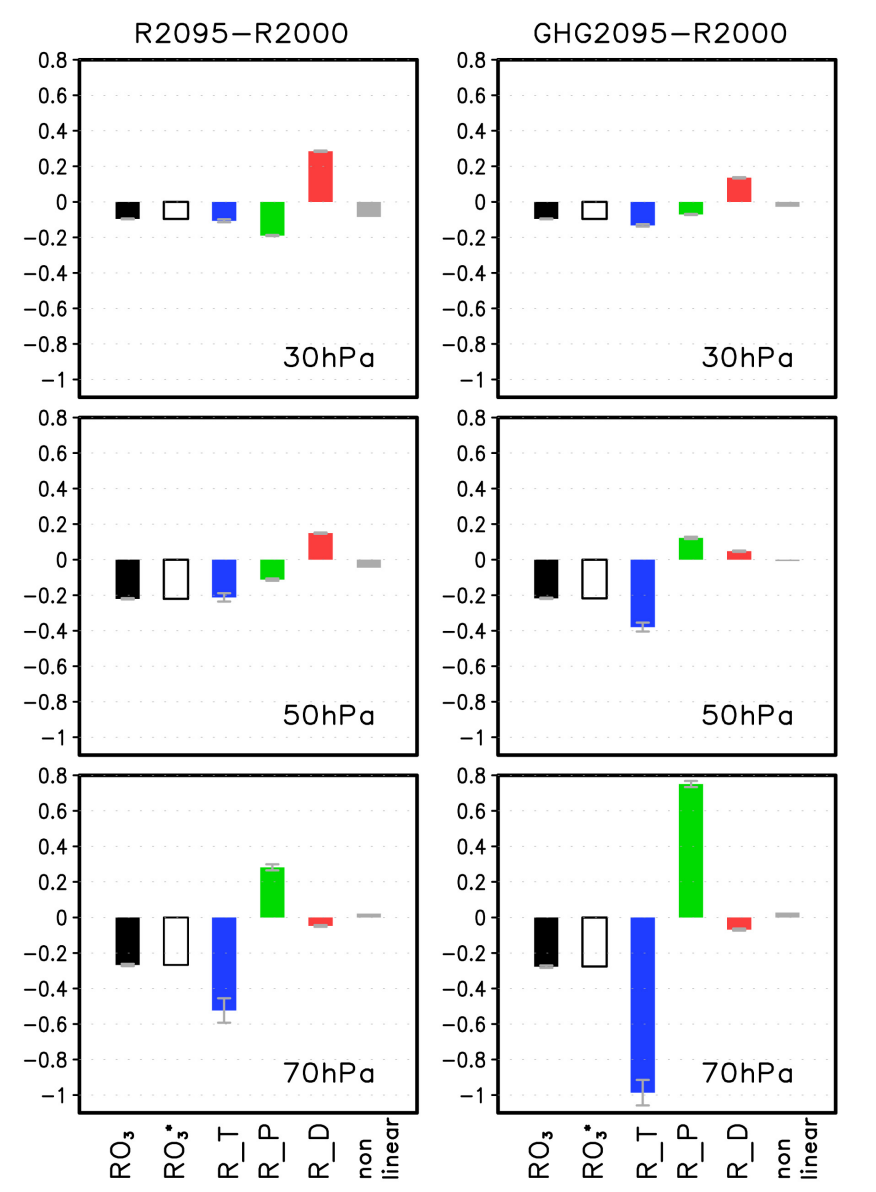

Fig. 3. The relative ozone change $\left(\mathrm{RO}_{3}\right)$, its contributions from transport (R_T), production (R_P) and destruction rate (R_D) and the sum of the contributions $\left(\mathrm{RO}_{3}^{*}\right)$ between $R 2095$ and $R 2000$ (left column) and between $G H G 2095$ and $R 2000$ (right column) in 70 (bottom), 50 (middle) and $30 \mathrm{hPa}$ (top) in the tropics $\left(25^{\circ} \mathrm{S}-25^{\circ} \mathrm{N}\right)$. For more details see text.

is produced (and the less destroyed) during the transit of the air parcel through the lower stratosphere, the larger the fraction that is transported out of this region within this air parcel. This means that the large relative ozone change that is attributed to transport is partly influenced by changes in the ozone production and loss.

In summary this analysis shows that the projected future ozone decrease in the tropical lower stratosphere not only will be induced by changes in ozone transport, but also will be affected by a modified ozone production and destruction.

To understand which processes cause the change in the mean monthly production and destruction, in the following the terms of ozone production and loss are further split into their individual pathways with the help of StratO3Bud and analysed in detail.

\subsection{Partitioning of ozone production and loss}

In Fig. 1 the partitioning of the annual mean total ozone production and ozone loss for the $R 2095$ simulation is compared to the partitioning for the $R 2000$ reference simulation. The relative contribution from $\mathrm{O}_{2}$ photolysis to the total production is slightly reduced in the future, and consequently the importance of the ozone production due to methane oxidation is slightly increased. Regarding the ozone loss, the relative contribution of the single loss cycles clearly changes from present to future conditions. A large reduction of the contribution from chlorine (from 23 to $9 \%$ at $2 \mathrm{hPa}$ ) as well as an increase in the contribution from $\mathrm{HO}_{\mathrm{x}}$ throughout the stratosphere are found. The contribution from $\mathrm{NO}_{\mathrm{x}}$ to the total ozone loss rises from $62 \%(R 2000)$ to $68 \%(R 2095)$ at $7 \mathrm{hPa}$. The relative importance of the $\mathrm{O}_{\mathrm{x}}$ cycle does not change below $10 \mathrm{hPa}$ but is slightly increased in the upper stratosphere.

\subsection{Contributions to ozone production and loss changes}

The annual mean ozone changes attributed to the different chemical production and destruction reactions are shown in Fig. 4a and b. A decrease in the ozone loss rate is equivalent to an increase in the local ozone abundance if the number of ozone molecules that are available for destruction is constant. Here, the relative change in ozone that results from a modified ozone chemistry and that is independent of the local ozone abundance is shown.

Changes in the reaction rates which lead to the ozone changes in Fig. 4 can be caused by changes in the number density of the involved compounds and, in the case of gas phase reactions, by changes in the temperature (see Fig. 6f) as the reaction rate coefficients $k$ can be temperature dependent. The number densities of species can be modified by both increased emissions and a colder and therefore denser stratosphere (Jonsson et al., 2004).

Before we discuss the results in detail, it should be pointed out that the ozone changes attributed to production and loss can differ between the offline (StratO3Bud, black) and the online (ProdLoss, black with circles) calculation method. No difference is found in the ozone changes due to production throughout the tropical stratosphere (black line over black line with circles). The ozone changes due to the online and the offline calculated loss, however, exhibit small but significant differences in the lower stratosphere (70-50 hPa) with larger changes for the online calculated loss. Nevertheless, they point in the same direction and a qualitative analysis of the contributions from the single loss reactions to the total ozone change is reasonable.

Above $\sim 50 \mathrm{hPa}$, the ozone production will decrease between 2000 and 2095 due to a reduced photolysis of oxygen. At lower altitudes, however, an increased ozone production is found for future conditions. At $70 \mathrm{hPa}$ this can mainly be attributed to an enhanced photolysis rate of molecular oxygen, 

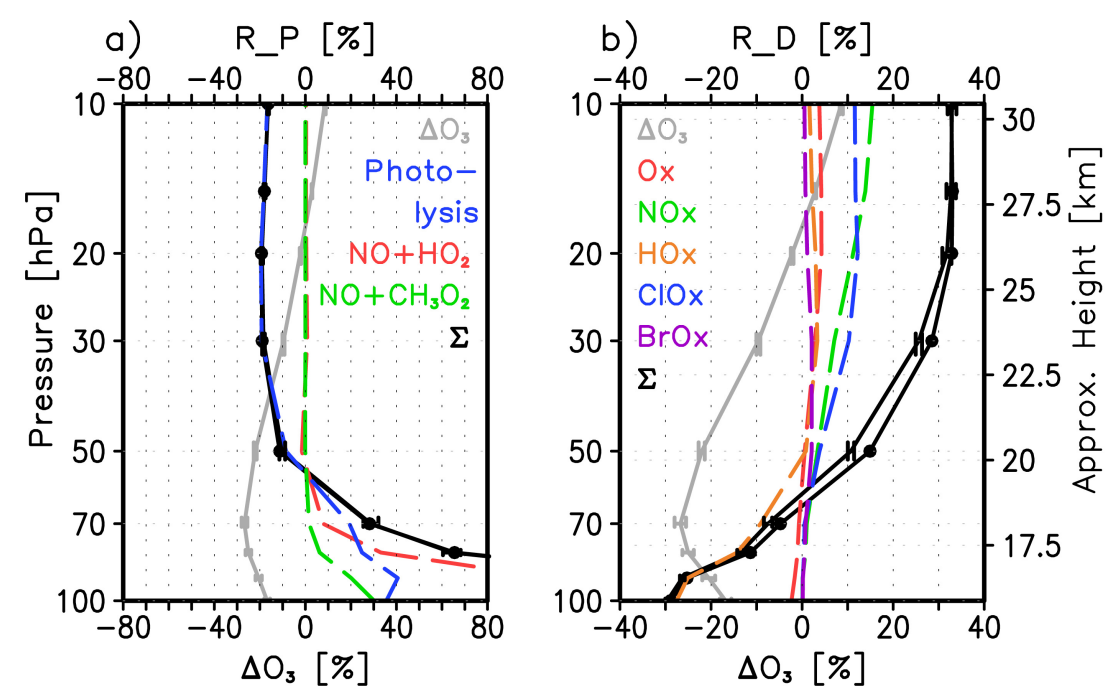

Fig. 4. Vertical profiles of the relative ozone changes (in \%) attributed to changes in ozone production (a) and ozone loss (b) relative to the respective sum ( $\Sigma$, black solid line) between the $R 2095$ and $R 2000$ simulations in the tropics $\left(25^{\circ} \mathrm{S}-25^{\circ} \mathrm{N}\right)$. Colours are as in Fig. 1 . In addition to the total changes $(\Sigma)$ the contributions from the different loss cycles and the three production pathways (coloured dashed lines) are shown. The grey line shows the relative change in ozone volume mixing ratio (scale on the bottom) which is equivalent to $\mathrm{RO}_{3}$. For comparison the total changes due to production and loss derived from ProdLoss are also included (black solid line with circles).

whereas in the lowermost stratosphere the changes in the rate of the reaction between $\mathrm{HO}_{2}$ and $\mathrm{NO}$ will dominate the increase in the ozone production. The decrease in the ozone production from photodissociation of oxygen in the middle and upper stratosphere is connected to the large ozone increase above $10 \mathrm{hPa}$ (see Fig. 2). This mechanism is known as the reversed "self-healing" effect of the ozone layer (e.g. Portmann and Solomon, 2007). Figure 5 shows the change of the partial ozone column existing above the particular pressure level for the tropics. Above $50 \mathrm{hPa}$ the ozone column is larger in the future scenario leading to a larger absorption of solar SW radiation at higher atmospheric levels. As a consequence the fraction of SW radiation penetrating to lower altitudes is reduced and hence the efficiency of photolytic ozone production is decreased. Due to the future decrease of ozone in the tropical lower stratosphere the difference in the partial ozone column has a maximum around $20 \mathrm{hPa}$ and decreases below, resulting in a smaller above laying ozone column in the lowermost stratosphere and also at the surface. This in turn explains the positive ozone changes due to photolysis at and below the $70 \mathrm{hPa}$ layer.

The grey line in Fig. 4 represents the relative ozone change averaged for the tropics (analogous to $\mathrm{RO}_{3}$ in Fig. 3). The comparison of the relative change in the ozone production and in the ozone mixing ratio shows that between 50 and $20 \mathrm{hPa}$ both the ozone production and the ozone abundance will decrease, whereas in the lowermost stratosphere (below $70 \mathrm{hPa}$ ) the production changes are opposite to the changes in ozone. This is consistent with the results in Fig. 3 and can now be explained by an increased ozone production via photolysis in the lowermost stratosphere that is partially caused by the dynamically induced reduction of the ozone column above. In the middle stratosphere, however, the ozone decrease due to transport is amplified because of the bulk of the ozone column in the upper stratosphere that leads to reduced ozone production (Fig. 5).

The total ozone loss rate, L (i.e. D. $\mathrm{O}_{3}$ ), is projected to decrease above $\sim 90 \mathrm{hPa}$ throughout the stratosphere (not shown). The corresponding ozone changes that are attributed to chemical destruction (Fig. 4b) are positive in the middle stratosphere, but negative at and below $\sim 70 \mathrm{hPa}$. This illustrates that the total loss rate, $\mathrm{L}$, which is generally used for analyses, is not only influenced by chemical processes but also by the ozone abundance itself. Furthermore, it is found, that future ozone changes below $50 \mathrm{hPa}$ are determined by a modified loss rate in the $\mathrm{HO}_{\mathrm{x}}$ cycle, while in the middle stratosphere the ozone increase related to chemical destruction is dominated by reduced loss rates in the $\mathrm{ClO}_{\mathrm{x}}$ and $\mathrm{NO}_{\mathrm{x}}$ cycles.

In the next step we examine which processes are responsible for the changes in the different loss cycles. Changes in the rate of catalytic loss cycles can be caused by changes in the abundance of the involved species or by changes in the reaction rate coefficient due to temperature changes. The reduction in the loss due to $\mathrm{ClO}_{\mathrm{x}}$ is primarily linked to the future decline of the stratospheric chlorine loading (Fig. 6c) which is a consequence of the regulation of the ODSs emissions. The decrease in the loss rate of the $\mathrm{NO}_{\mathrm{x}}$ cycle, however, is in contradiction to the future increase in the $\mathrm{N}_{2} \mathrm{O}$ emissions since one might expect that an increase in $\mathrm{N}_{2} \mathrm{O}$ entering the stratosphere will also lead to an increase in stratospheric $\mathrm{NO}_{\mathrm{x}}$. As Fig. 6a shows, this is not projected by the model 

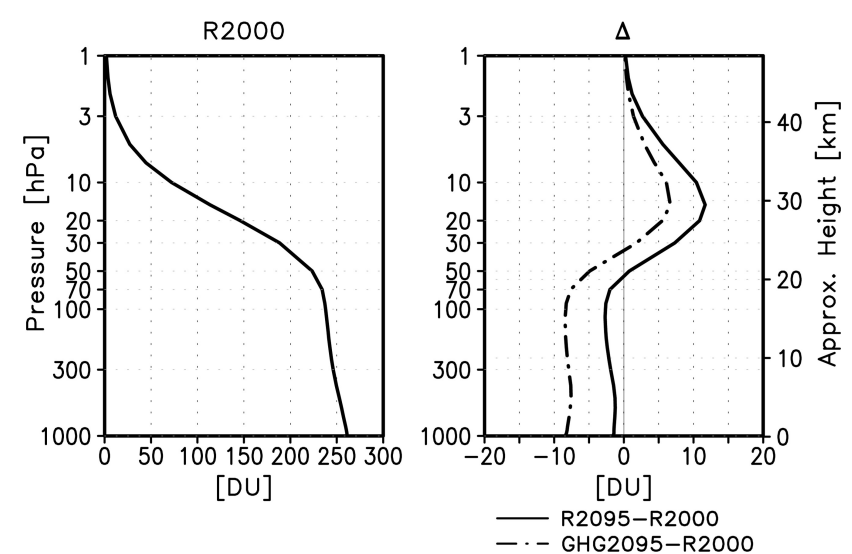

Fig. 5. Ozone column above each pressure level (in DU) in the tropics for the reference simulation (left) and the differences between the $R 2095$ and $R 2000$ (solid) and between GHG2095 and R2000 (dash-dotted) simulations (right).

simulations for the lower stratosphere. In fact, below $30 \mathrm{hPa}$ the $\mathrm{NO}_{\mathrm{x}}$ mixing ratios will decrease by up to $20 \%$ between the year 2000 and 2095. It is found that the ratio between $\mathrm{NO}_{y}$ (i.e. $\mathrm{NO}_{\mathrm{x}}+$ nitrogen reservoir species) and $\mathrm{N}_{2} \mathrm{O}$ decreases in the tropical lower stratosphere (not shown), which indicates a reduction in the release rate of $\mathrm{NO}_{\mathrm{y}}$ from $\mathrm{N}_{2} \mathrm{O}$. This can be related to a strengthening of the Brewer-Dobson circulation as mentioned by Revell et al. (2012). Besides a reduction of the transit time of air parcels due to increased tropical upwelling, the dynamically induced ozone decrease reduces the photolysis rate of ozone and hence the abundance of excited atomic oxygen in the lower stratosphere (not shown). Thus the release of $\mathrm{NO}_{\mathrm{y}}$ from $\mathrm{N}_{2} \mathrm{O}$ via the reaction $\mathrm{N}_{2} \mathrm{O}+\mathrm{O}^{1} \mathrm{D}$ decreases.

Since in the lower stratosphere the relative contribution from the catalytic $\mathrm{NO}_{\mathrm{x}}$ cycle to the total loss is small (Fig. 1), changes in the loss rate have only a small effect on ozone in this region. Between 30 and $10 \mathrm{hPa}$, however, a significant increase in ozone due to changes in the loss through $\mathrm{NO}_{\mathrm{x}}$ is found in Fig. 4b. At this altitude range no significant change in the $\mathrm{NO}_{\mathrm{x}}$ abundance will occur (Fig. 6a). It is found that the $\mathrm{NO}_{\mathrm{x}}$ abundance increases by up to $10 \%$ due to the decline in the chlorine abundance and hence a reduced formation of the reservoir species chlorine nitrate (not shown). This increase is compensated by the increased tropical upwelling which reduces the release rate of $\mathrm{NO}_{\mathrm{y}}$ (see above).

Nevertheless, a significant change in ozone is attributed to changes in the loss rate of the $\mathrm{NO}_{\mathrm{x}}$ cycle. In agreement with the explanation by Revell et al. (2012), the decreased efficiency of the $\mathrm{NO}_{\mathrm{x}}$ cycle is mainly caused by a smaller $\mathrm{O} / \mathrm{O}_{3}$ ratio (Fig. 6e) as the temperature decreases. In addition, the conversion of $\mathrm{NO}$ into $\mathrm{NO}_{2}$, which is the relevant compound in the rate determining step (Table 2), is reduced by the temperature induced slowing down of the reaction
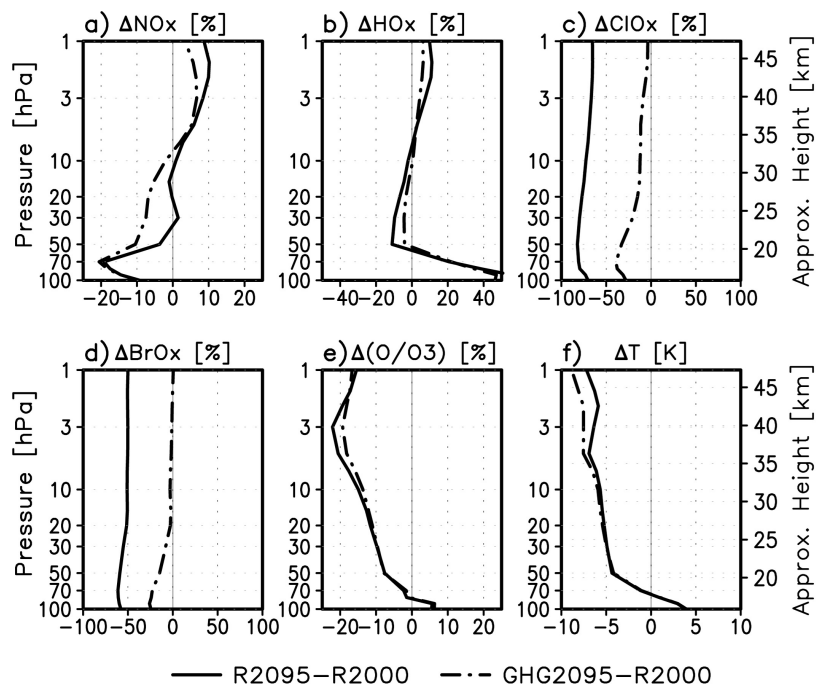

Fig. 6. Annual mean changes in the chemical families $\mathrm{NO}_{\mathrm{x}}(\mathbf{a})$, $\mathrm{HO}_{\mathrm{x}}(\mathbf{b}), \mathrm{ClO}_{\mathrm{x}}$ (c), $\mathrm{BrO}_{\mathrm{x}}$ (d) in $\%$, in the partitioning of $\mathrm{O}_{\mathrm{x}}$ in $\%$ (e) and in the temperature in $\mathrm{K}$ (f) between the $R 2095$ and $R 2000$ simulations (solid) and between the GHG2095 and R2000 simulations (dot-dashed) in the tropics $\left(25^{\circ} \mathrm{S}-25^{\circ} \mathrm{N}\right)$.

$\mathrm{NO}+\mathrm{O}_{3}$ and by a decrease in chlorine, which mitigates the reaction $\mathrm{NO}+\mathrm{ClO}$.

Changes in the rate of the catalytic loss cycle involving $\mathrm{HO}_{\mathrm{x}}$ radicals are partially linked to the changes in the $\mathrm{HO}_{\mathrm{x}}$ abundance (Fig. 6b). In the lowermost stratosphere $\mathrm{HO}_{\mathrm{x}}$ is influenced by an increased input of tropospheric water vapour due to a warmer tropopause region (e.g. Gettelman et al., 2010). The decrease in $\mathrm{HO}_{\mathrm{x}}$ between 50 and $10 \mathrm{hPa}$ is dominated by a large decrease in $\mathrm{HO}_{2}$ whereas $\mathrm{OH}$ will slightly increase. Since the reaction $\mathrm{H}_{2} \mathrm{O}+\mathrm{O}^{1} \mathrm{D}$ is a main source of $\mathrm{OH}$ in the tropical lower stratosphere (e.g. Hanisco et al., 2001), and the abundance of $\mathrm{O}^{1} \mathrm{D}$ will decrease in the future, a reduced formation of $\mathrm{OH}$ relative to the $\mathrm{H}_{2} \mathrm{O}$ increase will occur. The conversion of $\mathrm{OH}$ into $\mathrm{HO}_{2}$ occurs by the reaction of $\mathrm{OH}$ with $\mathrm{O}_{3}$. As ozone is reduced by transport and production changes and the cooling of the stratosphere slows the reaction rate of $\mathrm{OH}+\mathrm{O}_{3}$ down, the formation of $\mathrm{HO}_{2}$ decreases. All in all this results in a slight increase in $\mathrm{OH}$ and a decrease in $\mathrm{HO}_{2}$ and also in $\mathrm{HO}_{\mathrm{x}}$. A similar trend pattern is also shown in Oman et al. (2010). Regarding the change in ozone above $50 \mathrm{hPa}$ an increase in ozone is attributed to $\mathrm{HO}_{\mathrm{x}}$. Besides the decrease in $\mathrm{HO}_{2}$, the increase in $\mathrm{OH}$ is offset by the reduced reaction rate of $\mathrm{OH}+\mathrm{O}_{3}$ due to stratospheric cooling.

The reduction of the loss due to the $\mathrm{O}_{\mathrm{x}}$ cycle between 50 an $10 \mathrm{hPa}$ is caused by stratospheric cooling and the concomitant decrease of the ratio between atomic oxygen and ozone as well as the decrease of the temperature dependent reaction coefficient of the reaction $\mathrm{O}_{3}+\mathrm{O}^{3} \mathrm{P}$ (e.g. Jonsson et al., 2004). Below $70 \mathrm{hPa}$ a slightly increased ozone loss due 

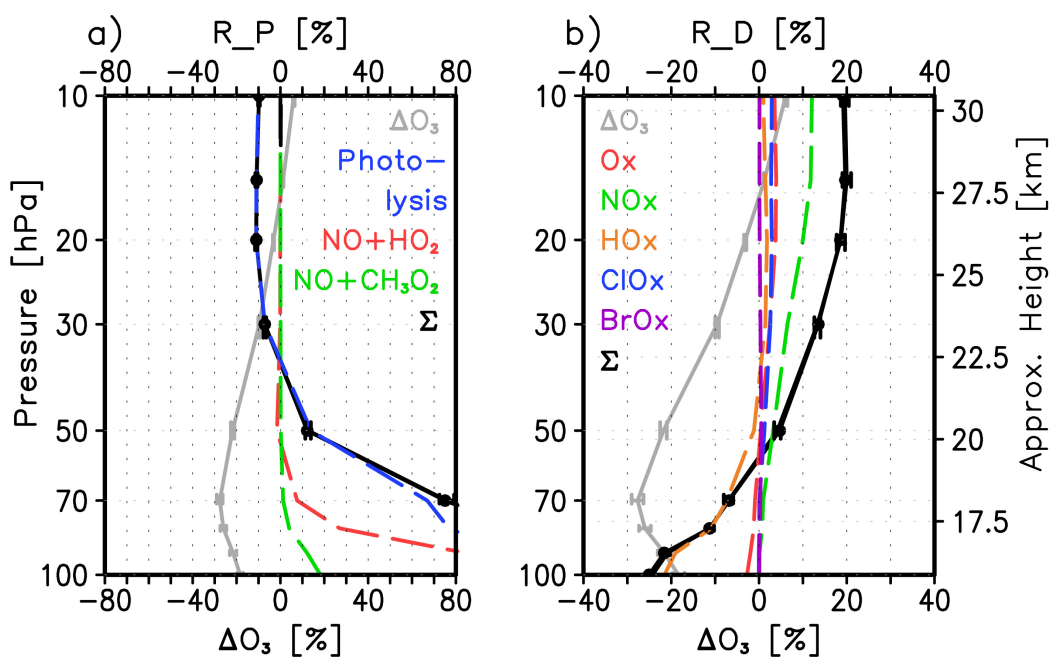

Fig. 7. Same as Fig. 4 but for the changes between the GHG2095 and R2000 simulation.

to $\mathrm{O}_{\mathrm{x}}$ is found that is related to the temperature increase of the tropical tropopause region (Fig. 6f).

Furthermore, a coupling between the different cycles can cause changes in the loss rates. An increase in $\mathrm{CH}_{4}$ will increase the amount of $\mathrm{Cl}$ sequestered as $\mathrm{HCl}$, while the increase in $\mathrm{H}_{2} \mathrm{O}$ and thus $\mathrm{OH}$ will increase the amount of nitrogen present as $\mathrm{HNO}_{3}$. This coupling leads to a mitigation of the $\mathrm{ClO}_{\mathrm{x}}$ and $\mathrm{NO}_{\mathrm{x}}$ cycles in addition to the decline in the abundance of reactive chlorine and nitrogen molecules.

In summary, in the tropical region between the tropopause and approximately $20 \mathrm{hPa}$, where a ozone decrease is projected between 2000 and the end of the 21 st century, a chemical contribution to the ozone trend is found in addition to the prominent role of ozone transport. An enhanced $\mathrm{HO}_{\mathrm{x}} \mathrm{cy}-$ cle slightly amplifies the negative ozone trend at the lower edge of this region while in the middle and upper part of this region the negative trend is reduced by less efficient $\mathrm{NO}_{\mathrm{x}}$ and $\mathrm{ClO}_{\mathrm{x}}$ cycles. Concurrently, the ozone change in this region is influenced by changes in the ozone production. In the lowermost tropical stratosphere an increase in ozone due to production counteracts the negative ozone change due to transport. The chemically induced ozone increase in the upper stratosphere, however, leads to a reduced ozone production in the middle stratosphere and thus to an enhancement of the negative ozone change above $\sim 50 \mathrm{hPa}$.

\subsection{Impact of increasing GHGs}

The detected changes in the chemical reaction rates are a combined effect of the increase in GHGs and the reduction of chlorine and bromine containing compounds in the stratosphere. With the help of the sensitivity simulation GHG2095, which is integrated with future GHG and SST boundary conditions, but present ODS levels, it is possible to isolate the impact of GHGs on the tropical ozone change. The right column of Fig. 3 illustrates that in the tropical lower strato- sphere the relative ozone changes $\left(\mathrm{RO}_{3}\right)$ are nearly equal to those derived when including a decline in ODSs. These changes are therefore driven by the impact of increasing GHGs only. However, the attribution of the relative ozone change to changes in transport, production, and destruction is clearly different, and hence also the specific role of the individual processes.

The relative ozone decrease due to transport is larger for the GHG2095 simulation at all three levels shown in Fig. 3. The increase due to production is larger at $70 \mathrm{hPa}$ and has even an opposite sign at $50 \mathrm{hPa}$ compared to the $R 2095 \mathrm{sim}-$ ulation. At the same time the relative ozone increase due to changes in the loss rates is smaller above $70 \mathrm{hPa}$. These findings are connected in the following way: the tropical upwelling does not significantly differ in the $R 2095$ and GHG2095 simulations (not shown). The larger ozone decrease due to transport is in fact the result of the increased ozone production via photolysis at 50 and $70 \mathrm{hPa}$ and of the smaller ozone decrease in $30 \mathrm{hPa}$ (see Fig. 7, left). The enhanced ozone production due to photodissociation is the consequence of the smaller ozone increase in the upper stratosphere related to a larger halogen loading in the GHG2095 simulation compared to R2095 (see Figs. 6c and 7b). Therefore the ozone column above is smaller than in the $R 2095$ simulation (Fig. 5), the difference to the $R 2000$ reference simulation is clearly reduced and more SW radiation can penetrate into the lower stratosphere.

The ozone changes attributed to modified destruction rates are smaller in the GHG2095 simulation, but not negligible. Figure 7b shows that the largest contribution to the ozone increase is from the $\mathrm{NO}_{\mathrm{x}}$ cycle. Even though the future changes in $\mathrm{NO}_{\mathrm{x}}$ differ in the $G H G 2095$ versus 2095 simulations in the middle stratosphere (Fig. 6a) due to an increased formation of chlorine nitrate in the GHG2095 simulation, the induced ozone change due to $\mathrm{NO}_{\mathrm{x}}$ is of comparable magnitude. 
This shows that the limitation by the available atomic oxygen is the more relevant mechanism in reducing the effectiveness of the $\mathrm{NO}_{\mathrm{x}}$ cycle.

Also without changing the emissions of the chlorine source gases, a slightly reduced loss due to the $\mathrm{ClO}_{\mathrm{x}}$ cycle contributes to the total change in the loss rate (up to $3 \%$ ). This has different reasons: on the one hand the coupling between the $\mathrm{NO}_{\mathrm{x}}$ and $\mathrm{ClO}_{\mathrm{x}}$ cycles leads to a reduced efficiency of the $\mathrm{ClO}_{\mathrm{x}}$ cycle when $\mathrm{NO}_{\mathrm{x}}$ is increased (above $10 \mathrm{hPa}$, see Fig. 6a). On the other hand, the fractional chlorine release from the organic source gases is reduced due to an increased upwelling by reducing the time available for photolysis (e.g. Waugh et al., 2007).

All in all future changes in the chemical production and loss rates are found to contribute to the ozone change in the tropical lower stratosphere. Due to a dynamically induced reduction of the overhead ozone column, the ozone production via $\mathrm{O}_{2}$ photolysis will increase at $70 \mathrm{hPa}$ and below. Concurrently this leads to a larger transport induced ozone change in this region. If the ODSs are fixed at the conditions for the year 2000 and only the changes in the GHG concentrations are considered, a similar ozone change is found in the tropical lower stratosphere. This shows that the opposed ozone changes that are induced by chemistry and transport are connected. The decline of ODSs in the future will lead to an increase in ozone in the middle and upper stratosphere and will counteract the dynamically induced reduction of the overhead ozone column. Hence the partial compensation of the transport induced ozone decrease is due to a combination of production and destruction changes.

\section{Conclusions}

The presented CCM simulations confirm the principal role of transport changes on the future evolution of tropical ozone in the lower stratosphere. However, it is found that in a future climate also the destruction and in particular the production of ozone in this region is modified. In the lowermost stratosphere the ozone production increases by $3 \%$ (mainly due to photolysis) leading to a relative ozone increase of almost $30 \%$. This increase is related to a reduced overhead ozone column. Above $70 \mathrm{hPa}$ the production is reduced with a maximum decrease of $15 \%$ at $10 \mathrm{hPa}$ because of an increased overhead ozone column. Accordingly, the resulting ozone change due to production above $70 \mathrm{hPa}$ is negative. Changes in the loss rate, especially of the $\mathrm{ClO}_{\mathrm{x}}$ and $\mathrm{NO}_{\mathrm{x}}$ cycles, do have a large relative contribution and lead to positive ozone changes above $70 \mathrm{hPa}$. In the lowermost stratosphere $(70 \mathrm{hPa})$ an intensified $\mathrm{HO}_{\mathrm{x}}$ cycle contributes to the ozone decrease.

The ozone transport is not only determined by the strength of the tropical upwelling, but also by the rate of chemical ozone production and loss in the rising air parcel. The contribution from circulation changes to the relative ozone change depends therefore also on the evolution of ozone in the upper stratosphere. If the ozone abundance further increases in the upper stratosphere, because of the growing emissions of GHGs and the concomitant stratospheric cooling, the ozone production in the lower stratosphere will decrease. Additionally, the ozone increase due to decreased destruction will grow less in the future, because the change that is attributed to the halogen decline will cease. This together can lead to a reduced net production and the effect of an enhanced tropical upwelling on ozone transport is reduced. A comparison to a hypothetical scenario without reducing the halogen emissions showed that the role of ozone transport in determining the negative ozone trend in the tropical lower stratosphere is more important, when the net ozone production increases rather than decreases.

\section{Supplementary material related to this article is available online at http://www.atmos-chem-phys.net/14/ 2959/2014/acp-14-2959-2014-supplement.zip.}

Acknowledgements. This work has been funded by the Deutsche Forschungsgemeinschaft (DFG) within the research unit SHARP (LA 1025/14-1 and LA 1025/13-1). We would like to thank Volker Grewe (DLR) for providing the ProdLoss routine and the ozone origin diagnostic. Furthermore, we would like to thank the North-German Supercomputing Alliance (HLRN) for computing time and support.

Edited by: W. Lahoz

\section{References}

Austin, J., Scinocca, J., Plummer, D., Oman, L., Waugh, D., Akiyoshi, H., Bekki, S., Braesicke, P., Butchart, N., Chipperfield, M., Cugnet, D., Dameris, M., Dhomse, S., Eyring, V., Frith, S., Garcia, R. R., Garny, H., Gettelman, A., Hardiman, S. C., Kinnison, D., Lamarque, J. F., Mancini, E., Marchand, M., Michou, M., Morgenstern, O., Nakamura, T., Pawson, S., Pitari, G., Pyle, J., Rozanov, E., Shepherd, T. G., Shibata, K., Teyssèdre, H., Wilson, R. J., and Yamashita, Y.: Decline and recovery of total column ozone using a multimodel time series analysis, J. Geophys. Res., 115, D00M10, doi:10.1029/2010JD013857, 2010.

Avallone, L. M. and Prather, M. J.: Photochemical evolution of ozone in the lower tropical stratosphere, J. Geophys. Res., 101, 1457-1461, doi:10.1029/95JD03010, 1996.

Baldwin, M. P., Gray, L. J., Dunkerton, T. J., Hamilton, K., Haynes, P. H., Randel, W. J., Holton, J . R., Alexander, M. J., Hirota, I., Horinouchi, T., Jones, D. B. A., Kinnersley, J. S., Marquardt, C., Sato, K. and Takahashi, M.: The quasi-biennial oscillation, Rev. Geophys., 29, 179-229, doi:10.1029/1999RG000073, 2001.

Bates, D. R. and Nicolet, M.: The photochemistry of atmospheric water vapor, J. Geophys. Res., 55, 301-327, doi:10.1029/JZ055i003p00301, 1950.

Bates, D. R. and Hays, P. B.: Atmospheric nitrous oxide, Planet. Space Sci., 15, 189-197, 1967. 
Chapman, S.: A Theory of Upper-Atmospheric Ozone, Mem. Roy. Meteorol. Soc., 3, 103-125, 1930.

Crutzen, P. J.: The influence of nitrogen oxides on the atmospheric ozone content, Q. J. Roy. Meteorol. Soc., 96, 320-325, doi:10.1002/qj.49709640815, 1970.

Crutzen, P. J. and Schmailzl, U.: Chemical Budgets of the Stratosphere, Planet. Space Sci., 31, 1009-1032, 1983.

Garny, H., Dameris, M., Randel, W., Bodeker, G. E., and Deckert, R.: Dynamically Forced Increase of Tropical Upwelling in the Lower Stratosphere, J. Atmos. Sci., 68, 1214-1233, doi:10.1175/2011JAS3701.1, 2011a.

Garny, H., Grewe, V., Dameris, M., Bodeker, G. E., and Stenke, A.: Attribution of ozone changes to dynamical and chemical processes in CCMs and CTMs, Geosci. Model Dev., 4, 271-286, doi:10.5194/gmd-4-271-2011, $2011 \mathrm{~b}$.

Gettelman, A., Hegglin, M. I., Son, S.-W., Kim, J., Fujiwara, M., Birner, T., Kremser, S., Rex, M., Añel, J. A., Akiyoshi, H., Austin, J., Bekki, S., Braesike, P., Brühl, C., Butchart, N., Chipperfield, M., Dameris, M., Dhomse, S., Garny, H., Hardiman, S. C., Jöckel, P., Kinnison, D. E., Lamarque, J. F., Mancini, E., Marchand, M., Michou, M., Morgenstern, O., Pawson, S., Pitari, G., Plummer, D., Pyle, J. A., Rozanov, E., Scinocca, J., Shepherd, T. G., Shibata, K., Smale, D., Teyssèdre, H., and Tian, W.: Multimodel assessment of the upper troposphere and lower stratosphere: Tropics and global trends, J. of Geophys. Res., 115, D00M08, doi:10.1029/2009JD013638, 2010.

Grewe, V.: The origin of ozone, Atmos. Chem. Phys., 6, 1495-1511, doi:10.5194/acp-6-1495-2006, 2006.

Haigh, J. D. and Pyle, J. A.: Ozone perturbation experiments in a two-dimensional circulation model, Q. J. Roy. Meteor. Soc., 108, 551-574, doi:10.1002/qj.49710845705, 1982.

Hanisco, T. F., Lanzendorf, E. J., Wennberg, P. O., Perkins, K. K., Stimpfle, R. M., Voss, P. B., Anderson, J. G., Cohen, R. C., Fahey, D. W., Gao, R. S., Hintsa, E. J., Salawitch, R. J., Margitan, J. J., McElroy, C. T., and Midwinter, C.: Sources, sinks, and the distribution of $\mathrm{OH}$ in the lower stratosphere, J. Phys. Chem. A, 105, 1543-1553, 2001.

IPCC (Intergovernmental Panel on Climate Change): Climate Change 1995: The Science of Climate Change. Contribution of Working Group I to the Second Assessment Report of the Intergovernmental Panel on Climate Change, edited by: Houghton, J. T., Meira Filho, L. G., Callander, B. A., Harris, N., Kattenberg, A., and Maskell, K., Cambridge University Press, Cambridge, UK and New York, USA, 1996.

IPCC (Intergovernmental Panel on Climate Change): Special Report on Emissions Scenarios: A Special Report of Working Group III of the Intergovernmental Panel on Climate Change, edited by: Nakicenovic, N. and Swart, R., Cambridge University Press, Cambridge, UK, 2000.

IPCC (Intergovernmental Panel on Climate Change) (2001), Climate change 2001: The Scientific Basis. Contribution of Working Group I to the Third Assessment Report, edited by: Houghton, J. T., Ding, Y., Griggs, D. J., Noguer, M., van der Linden, P. J., Dai, X., Maskell, K., and Johnson, C. A., Cambridge University Press, Cambridge, UK and New York, NY, USA.

IPCC/TEAP (Technology and Economic Assessment Panel): Special Report on Safeguarding the Ozone Layer and the Global Climate System: Issues Related to Hydrofluorocarbons and Perfluorocarbons, edited by: Metz, B., Kuijpers, L., Solomon, S.,
Andersen, S. O., Davidson, O., Pons, J., de Jager, D., Kestin, T., Manning, M., and Meyer, L., Cambridge University Press, Cambridge, UK, 2005.

Jöckel, P., Tost, H., Pozzer, A., Brühl, C., Buchholz, J., Ganzeveld, L., Hoor, P., Kerkweg, A. and Lawrence, M.: The atmospheric chemistry general circulation model ECHAM5/MESSy: consistent simulation of ozone from the surface to the mesosphere, Atmos. Chem. Phys., 6, 5067-5104, doi:10.5194/acp-6-5067-2006, 2006.

Johnston, H. and Kinnison, D. (1998), Methane photooxidation in the atmosphere: Contrast between two methods of analysis, J. Geophys. Res., 103, 21967-21984, 1998.

Johnston, H. S. and Podolske, J.: Interpretations of Stratospheric Photochemistry, Rev. Geophys. Space Phys., 16, 4, 491-519, 1978.

Jonsson, A. I., de Grandpre, J., Fomichev, V. I., McConnell, J. C. and Beagley, S. R.: Doubled $\mathrm{CO}_{2}$-induced cooling in the middle atmosphere: Photochemical analysis of the ozone radiative feedback, J. Geophys. Res., 109, D24103, doi:10.1029/2004JD005093, 2004.

Jungclaus, J. H., Botzet, M., Haak, H., Keenlyside, N., Luo, J. J., Latif, M., Marotzke, J., Mikolajewicz, U., and Roeckner, E.: Ocean circulation and tropical variability in the coupled model ECHAM5/MPI-OM, Journal of Climate, 19, 3952-3972, doi:10.1175/JCLI3827.1, 2006.

McIntyre, M. E. and Palmer, T. N.: The "surf zone" in the stratosphere, J. Atmos. Terr. Phys., 46, 9, 825-849, 1984.

Molina, M. J. and Rowland, F. S.: Stratospheric sink for chlorofluoromethanes: chlorine atomc-atalysed destruction of ozone, Nature, 249, 810-812, doi:10.1038/249810a0, 1974.

Newman, P. A., Daniel, J. S., Waugh, D. W., and Nash, E. R.: A new formulation of equivalent effective stratospheric chlorine (EESC), Atmos. Chem. Phys., 7, 4537-4552, doi:10.5194/acp7-4537-2007, 2007.

Nissen, K. M., Matthes, K., Langematz, U., and Mayer, B.: Towards a better representation of the solar cycle in general circulation models, Atmos. Chem. Phys., 7, 5391-5400, 2007.

Oberländer, S., Langematz, U. and Meul, S.: Unraveling impact factors for future changes in the Brewer-Dobson Circulation, J. Geophys. Res. Atmos., 118, 10296-10312, doi:10.1002/jgrd.50775, 2013.

Oman, L. D., Waugh, D. W., Kawa, S. R., Stolarski, R. S., Douglass, A. R., and Newman, P. A.: Mechanisms and feedback causing changes in upper stratospheric ozone in the 21 st century, J. Geophys. Res., 115, D05303, doi:10.1029/2009JD012397, 2010.

Oman, L. D., Plummer, D. A., Waugh, D. W., Austin, J., Scinocca, J., Douglass, A. R., Salawitch, R. J., Canty, T., Akiyoshi, H., Bekki, S., Braesicke, P., Butchart, N., Chipperfiled, M., Cugnet, D., Dhomse, S., Eyring, V., Frith, S., Hardiman, S. C., Kinnison, D. E., Lamarque, J. F., Mancini, E., Marchand, M., Michou, M., Morgenstern, O., Nakamura, T., Nielsen, J. E., Olivie, D., Pitari, G., Pyle, J., Rozanov, E., Shepherd, T. G., Shibata, K., Stolarski, R. S., Teyssedre, H., Tian, W., Yamashita, Y., and Ziemke, J. R.: Multi-model assessment of the factors driving stratospheric ozone evolution over the 21st century, Geophys. Res. Lett., 115, D24306, doi:10.1029/2010JD014362, 2010.

Plumb, R. A.: A 'tropical pipe' model of stratospheric transport, J. Geophys. Res., 101, 3957-3972, 1996. 
Portmann, R. W. and Solomon, S.: Indirect radiative forcing of the ozone layer during the 21st century, Geophys. Res. Lett., 34, L02813, doi:10.1029/2006GL028252, 2007.

Randel, W. J. and Wu, F.: Isolation of the Ozone QBO in SAGE II Data by Singular-Value decomposition, J. Atmos. Sci., 53, 17, 2546-2559, 1996.

Revell, L. E., Bodeker, G. E., Smale, D., Lehmann, R., Huck, P. E., Williamson, B. E., Rozanov, E., and Struthers, H.: The effectiveness of $\mathrm{N}_{2} \mathrm{O}$ in depleting stratospheric ozone, Geophys. Res. Lett., 39, L15806, doi:10.1029/2012GL052143, 2012.

Roeckner, E., Brokopf, R., Esch, M., Giorgetta, M., Hagemann, S., Kornblueh, L., Manzini, E., Schlese, U., and Schulzweida, U.: Sensitivity of Simulated Climate to Horizontal and Vertical Resolution in the ECHAM5 Atmosphere Model, J. Climate, 19, 3771-3791, doi:10.1175/JCLI3824.1, 2006.

Rosenfield, J. E., Douglass, A. R. and Considine, D. B.: The impact of increasing carbon dioxide on ozone recovery, J. Geophys. Res., 107, ACH 7-1-ACH 7-9, doi:10.1029/2001JD000824, 2002.

Sander, R., Kerkweg, A., Jöckel, P., and Lelieveld, J.: Technical note: The new comprehensive atmospheric chemistry module MECCA, Atmos. Chem. Phys., 5, 445-450, doi:10.5194/acp-5445-2005, 2005.

Sander, S. P., Friedl, R. R., Barker, J. R., Golden, D. M., Kurylo, M. J., Wine, P. H., Abbatt, J. P. D., Burkholder, J. B., Kolb, C. E., Moortgat, G. K., Huie, R. E., and Orkin, V. L.: JPL 2006: Chemical Kinetics and Photochemical Data for Use in Atmospheric Studies, Eval. 15, JPL Publication 06-2, Jet Propulsion Laboratory, Pasadena, available at: http://jpldataeval.jpl.nasa.gov (last access: March 2014), 2006
Seinfeld, J. H. and Pandis, S. N.: Atmospheric Chemistry and Physics: From Air Pollution to Climate Change, 2nd Edition, 1232 pp., John Wiley and Sons, Inc., Hoboken, New Jersey, 2006.

SPARC CCMVal: SPARC Report on the Evaluation of ChemistryClimate Models, edited by: Eyring, V., Shepherd, T. G., Waugh, D. W., SPARC Report No. 5, WCRP-132, WMO/TD-No. 1526, 2010.

Waugh, D. W., Strahan, S. E., and Newman, P. A.: Sensitivity of stratospheric inorganic chlorine to differences in transport, Atmos. Chem. Phys., 7, 4935-4941, doi:10.5194/acp-7-4935-2007, 2007.

Waugh, D. W., Oman, L., Kawa, S. R., Stolarski, R. S., Pawson, S., Douglass, A. R., Newman, P. A., and Nielsen, J. E.: Impacts of climate change on stratospheric ozone recovery, J. Geophys. Res., 36, L03805, doi:10.1029/2008GL036223, 2009.

World Meterological Organization (WMO): Scientific Assessment of Ozone Depletion: 2006, Global Ozone Research and Monitoring Project, Report No. 50, Geneva, Switzerland, 2007.

World Meterological Organization (WMO): Scientific Assessment of Ozone Depletion: 2010, Global Ozone Research and Monitoring Project, Report No. 52, Geneva, Switzerland, 2011. 